\title{
The Impact of School Culture on Serbian Primary Teachers' Job Satisfaction
}

\section{Okul Kültürünün Sırp İlköğretim Öğretmenlerinin İş Doyumu Üzerine Etkisi}

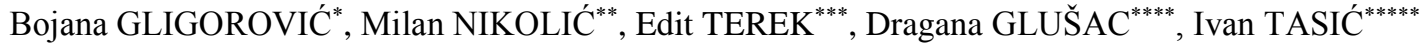

\begin{abstract}
This paper presents the results of research into the impact of school culture on teacher job satisfaction. The participants were 362 teachers from 57 primary schools in Serbia. Three dimensions of school culture (Teacher Professionalism and Goal Setting, Professional Treatment by the Administration, Teacher Collaboration) and nine dimensions of job satisfaction (Pay, Promotion, Supervision, Fringe Benefits, Contingent Rewards, Operating Procedures, Co-Workers, Nature of Work, Communication) were measured. The results indicate that all three dimensions of school culture are directly related to the job satisfaction of teachers in primary schools in Serbia, but that Professional Treatment by the Administration has the strongest influence. The teachers' gender and age were used as moderators of the relationship between the school culture dimensions and the job satisfaction dimensions. The results of hierarchical regression analysis show that the moderating effect of gender has been confirmed in two dimensions of job satisfaction: Fringe Benefits and Operating Procedures, while the moderating effect of age can be seen in four dimensions of job satisfaction: Fringe Benefits, Operating Procedures, Co-Workers and Communication. School culture has been shown to influence primary teachers' job satisfaction. Considering that school culture can be improved, it is possible to improve teachers' job satisfaction as well.
\end{abstract}

Keywords: school culture, teachers' job satisfaction, primary schools, teachers' gender and age, Serbia

ÖZ: Bu yazıda, öğretmen iş doyumunun okul kültürününe etkisine ilişkin araştırma sonuçlarını sunmaktadır. Katılımcılar Sırbistan'da bulunan 57 ilköğretim okulundan 362 öğretmenidir. Çalışmada; Okul kültürünün üç boyutu (Öğretmen-Profesyonellik ve Hedef Koyma, İdare tarafından Mesleki Muamele, Öğretmen İşbirliği) ve iş doyumunun dokuz boyutu (İş Ücreti, Promosyon, Denetleme, Maaş dışında Verilen Haklar, Grup Ödülleri, Çalışma yöntemi, İş arkadaşlıkları, İș niteliği, İletișim) ölçüldü. Sonuçlar, Sırbistan'daki ilköğretim okullarındaki öğretmenlerin iș doyumunun okul kültürünün her üç boyutuyla doğrudan ilişkili olduğunu göstermektedir. Ancak, İdare tarafindan Profesyonel muamelesinin en güçlü etkiye sahip olduğu görülmektedir. Öğretmenlerin cinsiyeti, yaşı ve okul kültürü ile iş doyumu boyutları arasındaki ilişski moderatör olarak kullanılmıştır. Hiyerarşik geri dönüş analizinden gelen sonuçlar cinsiyetin etkisinin iki boyutunu göstermektedir. Emeklilik sigortası ve Çalışma Usulleri ile yaşın 1lımlı etkisi iş tatmini dört boyutunu etkiler: Emeklilik sigortası, Çalışma Usulleri, İş arkadaşları ve İletişim. Okul kültürünün ilkokul öğretmenlerinin iş doyumunu etkilediği görülmektedir. Okul kültürü geliştirilebilir olmanın yanı sıra öğretmenlerin iş memnuniyetini de arttırıcı özelliğe sahip olduğu düşünülmektedir.

Anahtar kelimeler: Okul kültürü, öğretmenlerin iş doyumu, ilköğretim okulları, öğretmenlerin cinsiyeti ve yaşı, Sirbistan

*Corresponding author: M.Sc. in Technical Science, Dept. of Management, University of Novi Sad, Technical Faculty "Mihajlo Pupin", Zrenjanin, Serbia, e-mail: bojanagligorovic@gmail.com

** PhD in Technical Science, Dept. of Management, University of Novi Sad, Technical Faculty "Mihajlo Pupin”, Zrenjanin, Serbia

*** M.Sc. in Technical Science, Dept. of Management, University of Novi Sad, Technical Faculty "Mihajlo Pupin", Zrenjanin, Serbia

****PhD in Technical Science, Dept. of Information technology in education, University of Novi Sad, Technical Faculty "Mihajlo Pupin", Zrenjanin, Serbia

*****PhD in Technical Science, Dept. of Information technology in education, University of Novi Sad, Technical Faculty “Mihajlo Pupin”, Zrenjanin, Serbia 


\section{INTRODUCTION}

The success of every school depends on culture (Saphier \& King, 1985). There are many references that confirm the ability of school culture to influence different aspects of a school. It is closely related to the healthy and sustainable school development, the professional growth and well-being of the school members, the teaching and learning objectives (Fullan, 2001), and is central to academic success (Fullan, 2007). A positive and strong school culture is often considered as one in which students are more motivated to learn (Fyans \& Maehr, 1990) and meaningful staff development and enhanced student learning are encouraged and practiced (Engels et al., 2008). A collaborative school culture has a strong relationship with the students', motivation, achievement, and learning within a school (Demirtas, 2010; Lewis \& Wahlstrom, 2011). Heck and Marcoulides (1996) found that schools where positive social and professional relations among staff members were developed reported higher student achievement. Among nine characteristics of unusually effective schools Levine and Lezotte (1990) identified a productive school culture as the most important one. According to Anderman, Belzer and Smith (1991), school culture is both related to and highly predictive of teacher satisfaction and commitment. Cheng (1993) found that in a stronger school culture with shared participation, charismatic leadership, and intimacy, teachers experience higher job satisfaction and increased productivity. In their study Chen and Sun (1994), also showed that teacher job satisfaction is influenced by the environmental factors of the school. Stolp and Smith (1994), suggested that a school culture that is deeply felt and concerns strong traditions, ceremonies, rituals and symbols affects the productivity and satisfaction of teachers. School culture also impacts on teachers' attitudes toward their work. Ma and MacMillan's study (1999) confirmed that workplace conditions such as administrative control, teaching competence, and school culture positively affected teacher satisfaction. School culture can help teachers to find good solutions to overcome the obstacles and challenges they encounter in schools (Hancock \& Scherff, 2010), and evokes the energy of the teachers to perform the tasks required of them as well as promoting loyalty and commitment to the school and its ideals (Owens, 2004).

The purpose of this study is to explore whether school culture observed through three aspects: Teacher Professionalism and Goal Setting, Professional Treatment by the Administration and Teacher Collaboration has an impact on the dimensions of job satisfaction of primary teachers in Serbia. It is very important to understand the relations between school culture aspects and teacher job satisfaction because school culture can be changed and improved if all school members recognize the necessity for change and work together in order to achieve school culture improvement. By improving the school culture it is possible to improve teachers' job satisfaction which may have a positive impact on the effectiveness of Serbian primary schools. Furthermore, Serbian education has been facing many challenges and problems in the last few decades due to the direct and indirect influence of the transition process on the education system in Serbia leading to a decline in job satisfaction among teachers. Therefore, examining whether and how school culture impacts on teacher job satisfaction would be of significant importance for finding ways to increase Serbian teachers' job satisfaction especially in this era of difficulties, as well as in the future. An additional significance of the study is that similar ones have not been conducted in Serbia to date.

\subsection{Theoretical framework}

As a pervasive element of schools (Lindahl, 2006), school culture denotes the complex rituals that define the way a school operates (Waller, 1932). Similarly, Bolman and Deal (1997) describe school culture as the shared philosophies, ideologies, beliefs, feelings, assumptions, expectations, attitudes, and values that define how a school works, while Edwards, Green and Lyons (1996) conceptualize school culture as the common set of beliefs, values and practices held by the members of the school community about "the way things are done" in school. According to Deal 
and Kennedy (1999), school culture is a complex web of traditions and rituals that have been developed over time by teachers, students, parents, and administrators working together. Every school possesses a representative culture (Sergiovanni, 1984) which is not easy to describe because it involves the human beliefs, values and norms occurring within a school (Schein, 1985) and expresses the ways people operate within the school, the beliefs they adhere to, the assumptions that direct their behaviour, and the norms that create standards (Block, 1983). Seifert and Vornberg (2002) claim that school culture is the interaction, both inside and outside school, between stakeholders' attitudes and beliefs, the cultural norms of the school, and the relationships among individuals in the school. According to Pavlović and Oljača (2011), school culture arises from a subculture: the subculture of teachers, pupils, school principals, secretaries, and even a group of teachers for certain subjects. They are all developers of school culture, though the influence of the wider and immediate community or the social, demographic characteristics of the environment, and other influences cannot be excluded either, all of which as a whole can be divided into external and internal factors. These authors claim that everyone who visits a school can sense its culture at every given step: through employees' behaviour, the appearance of the walls in the corridors, or the presence or absence of shouting from pupils. Saphier and King (1985) argue that the teachers are those who shape culture. They have developed a questionnaire for school culture based on 12 norms: Collegiality, Experimentation, High expectations, Trust and confidence, Tangible support, Reaching out to the knowledge base, Appreciation and recognition, Caring, Celebration and humor, Involvement in decision making, Protection of what's important, Traditions and Honest, open communication. The questionnaire, School Culture Survey (Saphier \& King, 1985; as modified by Edwards, Green \& Lyons, 1996) integrates these norms in three dimensions: Teacher Professionalism and Goal Setting, Professional Treatment by Administration and Teacher Collaboration. In this paper school culture will be observed from those three aspects.

Job satisfaction indicates the overall quality of one's experiences in one's work role (Kalleberg \& Loscocco, 1983) and, according to Spector (1997), is a person's evaluation of his/her job and work context i.e. an attitude reflecting how well people like or dislike their job. Teacher job satisfaction refers to a teacher's affective relation to his or her teaching role and is a function of the perceived relationship between what one wants from teaching and what one perceives it is offering a teacher (Zembylas \& Papanastasiou, 2004). Lester (1982) defined teacher job satisfaction as the extent to which a teacher perceives and values various factors such as evaluation, collegiality, responsibility and recognition. Dinham (1995) argued that teachers derive their job satisfaction first from their relationships with students (both current and past) and second from their relationships with parents and colleagues.

There is a large number of papers dealing with the concrete problems related to the job satisfaction of teachers. Teacher job satisfaction is a complex concept which depends on a number of variables. Professional commitment significantly affects the job satisfaction of Nigerian teachers (Ladebo, 2005). Communication has an impact on teacher job satisfaction: organizational communication in primary schools influences the job satisfaction of teachers (De Nobile \& McCormick, 2008); and effective supervisory communication positively affects job satisfaction (Kim, 2002). In the reference (Butt \& Lance, 2005) teacher job satisfaction was examined in terms of workload and the work-life balance. Some references (Wong, Wong \& Peng, 2011; Brackett, Palomera, Mojsa-Kaja, Reyes, \& Salovey, 2010) show that emotional intelligence also impacts on the job satisfaction of teachers. Teacher job satisfaction has been positively related to school reform issues such as teacher professionalism, participative decisionmaking, teacher growth and empowerment, collegiality, perceptions of school climate, and workplace conditions (Ma \& McMillan, 1999; Stockard \& Lehman, 2004; Wu \& Short, 1996), which in turn improves the school effectiveness as a whole. Nevertheless, the study about job satisfaction of teachers shows that the social and cultural differences between countries must also be acknowledged (Kwong, Wang, \& Clifton, 2010). 
Working conditions and the working environment have an impact on the job satisfaction of female teachers (Schonfeld, 2000), while Aydin, Sarier and Uysal (2011) found that male teachers show higher levels of identification and internalization and make the values and norms of the school their own. The interaction young teachers experience with the other members of the school staff are rooted in the school culture, (Koberg \& Chusmir, 1987), so they are more influenced by it than those with more teaching experience.

\section{METHOD}

\subsection{Survey instruments (measures)}

School Culture. The School Culture Survey (SCS) (Saphier \& King, 1985; as modified by Edwards, Green \& Lyons, 1996) was used as an instrument for measuring school culture. Rasch and factor analysis by Edwards, Green and Lyons (1996) indicated that the School Culture Survey comprises three dimensions. The questionnaire contains 24 items and uses a 5-point Likert scale (1 - Almost never; 2 - Less often than not; 3 - About half the time; 4 - More often than not; and 5 - Almost always). The dimensions are: Teacher Professionalism and Goal Setting (10 items), Professional Treatment by the Administration ( 8 items) and Teacher Collaboration (6 items). Edwards, Green \& Lyons (1996) found the three dimensions to be conceptually coherent, with internal consistency reliabilities ranging from .81 to .91 . Item examples are: "Enough time is spent clarifying and understanding the goals of our school each year", I feel trusted and encouraged to make instructional decisions on my own ... and my boss backs me up when I do", "We talk in concrete and precise terms about things we're trying in our teaching".

Job satisfaction. Job satisfaction is measured by means of the Job Satisfaction Survey questionnaire (Spector, 1985). Although the survey was originally developed for use in human service organizations (community health centres, state psychiatric hospitals, state social service departments, nursing homes), it is applicable to all organizations, both in the public and private sectors. This questionnaire has 36 items relating to the nine dimensions of job satisfaction: Pay, Promotion, Supervision, Fringe Benefits, Contingent Rewards, Operating Procedures, CoWorkers, Nature of Work and Communication. The answers are measured by a 6-point Likert scale (1 - Strongly disagree; 2 - Disagree; 3 - Somewhat disagree; 4 - Somewhat agree; 5 Agree; 6 - Strongly agree). The instrument provides sufficient reliability and validity, with internal consistency reliabilities ranging from .60 to .82 . Some item examples are: "I feel I am being paid a fair amount for the work I do", "I like the people I work with", "Communications seem good within this organization".

\subsection{Participants and data collection}

The research was carried out in Serbian primary schools. The questionnaires were distributed personally to all the teachers in the sampled primary schools who expressed their opinion about culture as well as job satisfaction in their school through their responses. Besides items measuring the dimensions of school culture and job satisfaction, the questionnaire contained questions relating to general information about the teachers, including their gender and age which, in this study, were used as moderators to examine the relationship between the dimensions of school culture in primary schools and the dimensions of teachers' job satisfaction. The teachers completed the questionnaires during breaks between classes with a help of the examiner who presented the questionnaires to the teachers, provided some general instructions, answered to all questions that the respondents had while completing the questionnaire, and waited for teachers to complete the questionnaire. A total of $\mathrm{N}(0)=383$ teachers from 57 schools answered the questions. After the initial analysis, because of the significant dispersion of results, 21 questionnaires were rejected. The total number of respondents $\mathrm{N}=362$ consisted of 250 women and $112 \mathrm{men}$. This small sample number of men is the result of the employee structure in the Serbian education system (according to gender). According to the Statistical Office of the 
Republic of Serbia (2011), 67\% women and 33\% men are employed in our education system. If we observe primary schools, the percentage of women is even higher than in secondary schools and higher education. According to age, the subjects were divided into three groups: young teachers (up to 35 years), middle-aged teachers (35 to 50 years) and older teachers (over 50 years). The age of the respondents was as follows: 93 young teachers, 197 middle-aged teachers and 72 older teachers.

\section{FINDINGS}

The research results were obtained by applying descriptive statistics, correlation analysis, multiple regression analysis, and hierarchical regression analysis in order to test the moderating effects of gender and age on the dimensions of school culture and job satisfaction of teachers. The results of the research follow below.

\subsection{Descriptive statistics}

The descriptive statistics for the dimensions of school culture and job satisfaction are shown in Table 1. In the table, among other things, the names of the dimensions, the short names for each dimension (which are used hereafter), mean size, standard deviation and Cronbach's Alpha, are given for each dimension. The values of Cronbach's Alpha range in the interval from $\alpha$ $=0.703$ to $\alpha=0.949$.

Table 1: Descriptive statistics

\begin{tabular}{lcccccc}
\hline \multicolumn{1}{c}{ Dimensions } & $\begin{array}{c}\text { Short } \\
\text { name }\end{array}$ & Min. & Max. & Mean & Std. Dev. $\begin{array}{c}\text { Cronbach's } \\
\text { Alpha }\end{array}$ \\
\hline Teacher Professionalism and Goal Setting & SC1 & 1.10 & 5.00 & 3.9390 & .81384 & .949 \\
Professional Treatment by Administration & SC2 & 1.00 & 5.00 & 3.7510 & .83444 & .919 \\
Teacher Collaboration & SC3 & 1.00 & 5.00 & 3.8310 & .83305 & .892 \\
\hline Pay & JS1 & 1.00 & 6.00 & 3.0711 & 1.04518 & .709 \\
Promotion & JS2 & 1.00 & 6.00 & 3.4710 & 1.31547 & .845 \\
Supervision & JS3 & 1.00 & 6.00 & 4.6906 & 1.14312 & .870 \\
Fringe benefits & JS4 & 1.00 & 6.00 & 2.9544 & 1.34867 & .838 \\
Contingent rewards & JS5 & 1.00 & 6.00 & 3.5753 & 1.29203 & .838 \\
Operating procedures & JS6 & 1.00 & 6.00 & 3.2106 & 1.04305 & .703 \\
Co-Workers & JS7 & 1.75 & 6.00 & 4.5981 & .93377 & .784 \\
Nature of work & JS8 & 1.50 & 6.00 & 5.2666 & .84890 & .855 \\
Communication & JS9 & 1.00 & 6.00 & 4.8094 & .95043 & .827 \\
\hline Valid N (list wise) & 362 & & & & & \\
\hline
\end{tabular}

\subsection{Correlation analysis}

In Table 2 the results of correlation analysis are presented: the correlation dimension of school culture and dimensions of job satisfaction. These results refer to the total sample of $\mathrm{N}=$ 362 respondents. Pearson correlation is used. Statistically significant correlations are indicated as follows: $* \mathrm{P}<0.05$; ** $\mathrm{p}<0.01$. It may be noted that all correlations are statistically significant $* *$ $\mathrm{p}<0.01$.

Table 2: Pearson coefficients of correlation between school culture and job satisfaction dimensions

\begin{tabular}{lccccccccc}
\hline & JS1 & JS2 & JS3 & JS4 & JS5 & JS6 & JS7 & JS8 & JS9 \\
\hline SC1 & $.455 * *$ & $.552 * *$ & $.640 * *$ & $.386 * *$ & $.574 * *$ & $.418 * *$ & $.722 * *$ & $.524 * *$ & $.774 * *$ \\
SC2 & $.502 * *$ & $.599 * *$ & $.636 * *$ & $.455 * *$ & $.627 * *$ & $.440 * *$ & $.661 * *$ & $.488 * *$ \\
SC3 & $.433 * *$ & $.494 * *$ & $.491 * *$ & $.382 * *$ & $.549 * *$ & $.365 * *$ & $.589 * *$ & $.394 * *$ & $.644 * *$
\end{tabular}




\subsection{Regression analysis}

Multiple Regression analysis was used to determine the predictive effects of school culture dimensions (independent variables) on job satisfaction (dependent variable). The results of the regression analysis are shown in Table 3. The bold values denote statistically significant coefficients.

Table 3: Regression analysis (Dependent Variable: JS dimensions; Predictors: SC dimensions)

\begin{tabular}{|c|c|c|c|c|c|c|c|}
\hline Dependent & Independent & B & $\mathbf{t}$ & Sig. & $\mathbf{R}^{2}$ & $\mathbf{F}$ & F Sig. \\
\hline \multirow{3}{*}{ JS1 - Pay } & $\mathrm{SC} 1$ & -.050 & -.433 & .666 & \multirow{3}{*}{.255} & \multirow{3}{*}{40.784} & \multirow{3}{*}{.000} \\
\hline & $\mathrm{SC2}$ & .479 & 4.100 & .000 & & & \\
\hline & $\mathrm{SC} 3$ & .086 & 1.054 & .292 & & & \\
\hline \multirow{3}{*}{ JS2 - Promotion } & $\mathrm{SC} 1$ & .024 & .220 & .826 & \multirow{3}{*}{.359} & \multirow{3}{*}{66.883} & \multirow{3}{*}{.000} \\
\hline & SC2 & .562 & 5.188 & .000 & & & \\
\hline & SC3 & .020 & .260 & .795 & & & \\
\hline \multirow[t]{2}{*}{ JS3 - Supervision } & $\mathrm{SC2}$ & .377 & 3.704 & .000 & \multirow[t]{2}{*}{.433} & \multirow[t]{2}{*}{91.151} & \multirow[t]{2}{*}{.000} \\
\hline & SC3 & -.153 & -2.158 & .032 & & & \\
\hline \multirow{3}{*}{$\begin{array}{l}\text { JS4 - Fringe } \\
\text { benefits }\end{array}$} & $\mathrm{SC} 1$ & -.205 & -1.727 & .085 & \multirow{3}{*}{.214} & \multirow{3}{*}{32.585} & \multirow{3}{*}{.000} \\
\hline & $\mathrm{SC2}$ & .579 & 4.835 & .000 & & & \\
\hline & SC3 & .078 & .937 & .349 & & & \\
\hline \multirow{2}{*}{$\begin{array}{l}\text { JS6 - Operating } \\
\text { procedures }\end{array}$} & $\mathrm{SC2}$ & .343 & 2.827 & .005 & \multirow[t]{2}{*}{.195} & \multirow[t]{2}{*}{28.908} & \multirow[t]{2}{*}{.000} \\
\hline & SC3 & .006 & .076 & .940 & & & \\
\hline \multirow{3}{*}{ JS7 - Co-Workers } & SC1 & .703 & 7.567 & .000 & \multirow{3}{*}{.522} & \multirow{3}{*}{130.059} & \multirow{3}{*}{.000} \\
\hline & $\mathrm{SC} 2$ & .007 & .079 & .937 & & & \\
\hline & SC3 & .016 & .244 & .808 & & & \\
\hline \multirow{3}{*}{$\begin{array}{l}\text { JS8 - Nature of } \\
\text { work }\end{array}$} & SC1 & .512 & 4.494 & .000 & \multirow{3}{*}{.279} & \multirow{3}{*}{46.153} & \\
\hline & $\mathrm{SC} 2$ & .107 & .936 & .350 & & & .000 \\
\hline & $\mathrm{SC} 3$ & -.107 & -1.333 & .183 & & & \\
\hline & SC1 & .679 & 8.004 & .000 & & & \\
\hline $\begin{array}{l}\text { JS9 - } \\
\text { Communication }\end{array}$ & $\mathrm{SC} 2$ & .071 & .831 & .407 & .601 & 179.784 & .000 \\
\hline
\end{tabular}

\subsection{Gender as a moderator of the relationships between SC dimensions and JS dimensions}

The results of correlation analysis for the dimensions of school culture and those of job satisfaction, especially for women and men, are shown in Table 4.

Table 4: Correlation coefficients between SC dimensions and JS dimensions for women and men

\begin{tabular}{|c|c|c|c|c|c|c|c|c|c|c|}
\hline \multicolumn{2}{|c|}{ Gender } & JS1 & JS2 & JS3 & JS4 & JS5 & JS6 & JS7 & JS8 & JS9 \\
\hline \multirow{3}{*}{ Men } & SC1 & $.411^{* * *}$ & $.519^{* * *}$ & $.583^{* *}$ & $.268^{*}$ & $.541^{* *}$ & $.259^{*}$ & $.691^{* * *}$ & $.616^{* * *}$ & $.743^{* * *}$ \\
\hline & $\mathrm{SC} 2$ & $.427^{* *}$ & $.513^{* *}$ & $.566^{* * *}$ & $.319^{* *}$ & $.543^{* *}$ & $.294^{*}$ & $.610^{* *}$ & $.557^{* *}$ & $.696^{\text {** }}$ \\
\hline & SC3 & $.454^{* * *}$ & $.466^{* * *}$ & $.449^{* * *}$ & $.314^{* * *}$ & $.485^{\text {** }}$ & .163 & $.494^{* *}$ & $.481^{* * *}$ & $.593^{\text {*** }}$ \\
\hline \multirow{3}{*}{ Women } & SC1 & $.469^{* * *}$ & $.560^{* * *}$ & $.656^{* * *}$ & $.420^{* * *}$ & $.584^{* * *}$ & $.462^{* * *}$ & $.731^{* * *}$ & $.497^{* * *}$ & $.783^{* * *}$ \\
\hline & $\mathrm{SC} 2$ & $.525^{* *}$ & $.623^{* * *}$ & $.657^{* *}$ & $.496^{* *}$ & $.652^{* *}$ & $.481^{* *}$ & $.675^{* *}$ & $.467^{* *}$ & $.728^{* * *}$ \\
\hline & SC3 & $.429^{* *}$ & $.501^{\text {** }}$ & $.503^{* *}$ & $.402^{* *}$ & $.566^{* *}$ & $.417^{* *}$ & $.614^{* *}$ & $.368^{* *}$ & $.657^{* *}$ \\
\hline
\end{tabular}

To test the moderating effect of gender hierarchical regression analysis was used. Hierarchical regression was used to analyze the significance of the regression coefficient of the product predictor variable for the independent variable $\mathrm{SCi}$, the dependent variable JSi and the 
moderating variable gender. The results of the hierarchical regression analysis are presented in Table 5 (only those results where a moderating effect of gender is confirmed).

Table 5: Hierarchical regression analysis with gender as a moderator

\begin{tabular}{cccc}
\hline Independent variable & Dependent variable & R square & F-change \\
\hline \multirow{2}{*}{ SC1 } & \multirow{2}{*}{ JS6 } & .175 & 76.271 \\
& & .180 & 2.249 \\
& & .191 & 4.670 \\
\hline \multirow{3}{*}{ SC2 } & \multirow{2}{*}{ JS4 } & .207 & 94.243 \\
& & .212 & 1.936 \\
& \multirow{3}{*}{ JS6 } & .221 & 4.106 \\
\cline { 3 - 4 } & & .193 & 86.213 \\
& & .198 & 2.207 \\
SC3 & \multirow{2}{*}{ JS6 } & .209 & 4.924 \\
& & .133 & 55.444 \\
& & .138 & 1.886 \\
& &
\end{tabular}

\subsection{Age as a moderator of the relationships between SC dimensions and JS dimensions}

The results of correlation analysis for the dimensions of school culture and those of job satisfaction, for young teachers, middle-aged teachers and older teachers, are presented in Table 6.

Table 6: Correlation coefficients between SC dimensions and JS dimensions for young, middle-aged and older teachers

\begin{tabular}{|c|c|c|c|c|c|c|c|c|c|c|}
\hline Age & & JS1 & JS2 & JS3 & JS4 & JS5 & JS6 & JS7 & JS8 & JS9 \\
\hline \multirow{3}{*}{$\begin{array}{l}\text { Young } \\
\text { teachers }\end{array}$} & $\mathrm{SC} 1$ & $.452^{* * *}$ & $.619^{* * *}$ & $.682^{* * *}$ & $.480^{* *}$ & $.642^{* * *}$ & $.437^{* * *}$ & $.812^{* *}$ & $.554^{* * *}$ & $.840^{* * *}$ \\
\hline & $\mathrm{SC} 2$ & $.513^{* *}$ & $.634^{* *}$ & $.610^{* *}$ & $.533^{* *}$ & $.685^{* *}$ & $497^{* *}$ & $.744^{* *}$ & $.514^{* *}$ & $.748^{* *}$ \\
\hline & SC3 & $.412^{* *}$ & $.562^{* *}$ & $.582^{* *}$ & $.406^{* *}$ & $.565^{* *}$ & $.388^{* *}$ & $.740^{* *}$ & $.490^{* *}$ & $.705^{* *}$ \\
\hline \multirow{3}{*}{$\begin{array}{l}\text { Middle-aged } \\
\text { teachers }\end{array}$} & SC1 & $.504^{* * *}$ & $.571^{* *}$ & $.595^{* *}$ & $.437^{* * *}$ & $.583^{* * *}$ & $.456^{* *}$ & $.703^{* *}$ & $.486^{* * *}$ & $.734^{* *}$ \\
\hline & $\mathrm{SC} 2$ & $.535^{* *}$ & $.628^{* *}$ & $.617^{* *}$ & $.490^{* * *}$ & $.634^{* * *}$ & $.460^{* *}$ & $.648^{* *}$ & $.457^{* *}$ & $.706^{* *}$ \\
\hline & $\mathrm{SC} 3$ & $.436^{* *}$ & $.482^{* *}$ & $.419^{* *}$ & $.414^{* *}$ & $.569^{* * *}$ & $.393^{* *}$ & $.550^{* *}$ & $.326^{* *}$ & $.621^{* *}$ \\
\hline \multirow{3}{*}{ Older teachers } & $\mathrm{SC} 1$ & $.396^{* * *}$ & $.488^{* *}$ & $.734^{* *}$ & .216 & $.526^{* * *}$ & $.360^{* *}$ & $.672^{* *}$ & $.549^{* *}$ & $.784^{* *}$ \\
\hline & $\mathrm{SC} 2$ & $.447^{* *}$ & $.519^{* *}$ & $.732^{* *}$ & $328^{* * *}$ & $.584^{* * *}$ & $370^{* * *}$ & $.608^{* *}$ & $.515^{* *}$ & $.746^{* *}$ \\
\hline & $\mathrm{SC} 3$ & $.470^{* *}$ & $.481^{* *}$ & $.603^{* *}$ & $.314^{* *}$ & $.521^{* *}$ & $.336^{\text {** }}$ & $.524^{* *}$ & $.406^{* *}$ & $.651^{* *}$ \\
\hline
\end{tabular}

To test the moderating effect of age hierarchical regression analysis was used. Hierarchical regression was used to analyze the significance of the regression coefficient of the product predictor variable for the independent variable $\mathrm{SCi}$, the dependent variable JSi and moderating variable age. The results of the hierarchical regression analysis are presented in Table 7 (only those results where a moderating effect of age is confirmed). 
Table 7: Hierarchical regression analysis with age as a moderator

\begin{tabular}{|c|c|c|c|}
\hline Independent variable & Dependent variable & R square & F-change \\
\hline \multirow{9}{*}{$\mathrm{SC} 1$} & \multirow{3}{*}{ JS4 } & .149 & 63.027 \\
\hline & & .157 & 3.409 \\
\hline & & .168 & 4.667 \\
\hline & \multirow{3}{*}{ JS7 } & .521 & 392.178 \\
\hline & & .521 & .055 \\
\hline & & .530 & 6.666 \\
\hline & \multirow{3}{*}{ JS9 } & .599 & 538.389 \\
\hline & & .600 & .560 \\
\hline & & .609 & 8.269 \\
\hline \multirow{12}{*}{$\mathrm{SC} 2$} & \multirow{3}{*}{ JS4 } & .207 & 94.243 \\
\hline & & .213 & 2.619 \\
\hline & & .223 & 4.311 \\
\hline & \multirow{3}{*}{ JS6 } & .193 & 86.213 \\
\hline & & .193 & .115 \\
\hline & & .204 & 4.554 \\
\hline & \multirow{3}{*}{ JS7 } & .437 & 279.031 \\
\hline & & .437 & .374 \\
\hline & & .446 & 5.925 \\
\hline & \multirow{3}{*}{ JS9 } & .519 & 388.960 \\
\hline & & .521 & 1.353 \\
\hline & & .527 & 4.422 \\
\hline \multirow{6}{*}{$\mathrm{SC} 3$} & \multirow{3}{*}{ JS7 } & .347 & 191.286 \\
\hline & & .349 & 1.133 \\
\hline & & .364 & 8.245 \\
\hline & \multirow{3}{*}{ JS9 } & .414 & 254.609 \\
\hline & & .419 & 2.662 \\
\hline & & .427 & 4.999 \\
\hline
\end{tabular}

\section{DISCUSSION and RESULTS}

Table 2 shows a statistically significant correlation between the dimensions of school culture and the dimensions of job satisfaction in primary schools in Serbia. All correlations are strong and positive.

From the dimensions of school culture the most influential on teachers' job satisfaction is SC2 - Professional Treatment by the Administration. If administrators trust teachers' professional judgment and show confidence in their ability to carry out their professional development and to design instructional activities, the teachers will be more satisfied with their jobs. Teaching is to a great extent a creative profession where freedom at work is essential. According to Skaalvik \& Skaalvik (2009), when school administrators are perceived by teachers as supporters, as those who place confidence in them and provide autonomy, the teachers' job satisfaction level significantly increases. Ingersoll and Smith (2003) found that teachers who were dissatisfied with their jobs often identified a lack of administrative support as the primary cause. The context provided by the administration influences interaction among staff, teachers' feelings of being valued for their work, and the sense of substantive involvement in the operation of the school (Darling-Hammond, 1995).

The dimension SC1 - Teacher Professionalism and Goal Setting also has a strong influence on the job satisfaction of teachers. The clearer the teachers' collective vision of what they want for their students, and the stronger the willingness to continually improve their instruction in order to create an optimal learning environment for their pupils is, the higher the level of teacher job satisfaction will be. Similarly, in their study Beck \& Murphy (1996) found that the 
importance of ongoing professional development was highly recognized by teachers who were satisfied with their jobs.

The weakest correlation exists between the Teacher Collaboration dimension - SC3 and job satisfaction. This is not surprising considering some opinions that teaching is quite an autonomous profession (Clement \& Vandenberghe, 2000), where work is accomplished largely alone, and collaboration is a relatively rare occurrence (Hargreaves, 1993). In a study of teachers in China, Weiqi (2008) found that collegial relations among teachers were weakly related to job satisfaction. However, the correlations between Teacher Collaboration - SC3 and teachers' job satisfaction are still strong and positive, which means that teachers who help each other and create an open atmosphere in which problems can be discussed feel more satisfied with their jobs.

Table 3 shows the high values of the corrected determination indexes of R2, which are in the range from 0.195 to 0.601 . Based on the value $R 2$, the following dimensions of job satisfaction fall under the biggest influence of school culture: JS9 - Communication $\left(R^{2}=0.601\right)$ and JS7 - Co-Workers $(\mathrm{R} 2=0.522)$. Although SC3 - Teacher Collaboration has the least influence on the overall job satisfaction of teachers, those dimensions of job satisfaction that are directly related to collaboration are most influenced by school culture. Considering the nature of teaching as a profession, collaboration, by itself, is not so important to teachers and does not influence their job satisfaction to the same extent as other dimensions of school culture. However, the dimensions of school culture have the greatest influence on satisfaction with co-workers and communication, since without positive relationships among school members; teachers cannot work professionally and set professional goals. If these relationships do not exist, teachers share deep feelings of dissatisfaction (Cockburn, 2000). From Table 3 it can be seen that from the three dimensions of school culture, SC2 - Professional Treatment by the Administration has the greatest impact on teacher job satisfaction, followed by SC1 - Teacher Professionalism and Goal Setting and SC3 - Teacher Collaboration. These results are consistent with the results of the correlation analysis.

Dependent variable JS1 - Pay is under the influence of SC2 - Professional Treatment by the Administration. In numerous studies, (Hargreaves, 1994; Dinham \& Scott, 1998; Osborn et al., 2000; Van den Berg, 2002), low pay is a factor that has been linked to teachers' dissatisfaction. Work in primary schools in Serbia is not paid and rewarded enough, and the reputation of the profession has deteriorated in the past two to three decades. The dimension JS1 Pay has a very low average value in comparison with the other dimensions of job satisfaction (Table 1). The results of regression analysis reveal that fair and supportive treatment by the school administration increases Serbian teachers' satisfaction with pay. When teachers are given the opportunity to improve their professional skills and participate in decision-making they are willing to overlook low salaries. Xiaofu and Qiwen (2008) also found that teachers' satisfaction with their wages was to some extent influenced by a school's positive administrative climate.

According to regression analysis, Serbian primary teachers' satisfaction with promotion JS2 is influenced by Professional Treatment by the Administration - SC2. In their study, Xiaofu and Qiwen (2008) revealed that teachers' satisfaction with opportunities for advanced studies and promotion was based on a good administrative and study climate. Although promotion prospects for teachers in Serbian primary schools are very limited, mainly based on political connections and obsequious behaviour toward school administrators rather than on teachers' achieved professional results, teachers are ready to neglect this lack of fairness in the promotion system if they are treated professionally, since sometimes fair and professional treatment can lead to promotion prospects.

In the case of dependent variable JS3 - Supervision, it can be seen to be influenced by all three dimensions of school culture. The relation between SC1 - Teacher Professionalism and Goal Setting and JS3 - Supervision can be explained as follows. School principals - supervisors should 
form new values, norms and beliefs at school and share them with the school members. Every teacher, as a professional, has his/her own educational and professional goals, values and beliefs on different issues regarding teaching, students, educational methods and so on (Skaalvik \& Skaalvik, 2011). If the teachers' educational and professional goals, values and beliefs are in congruence with those emphasized in the school, they will be more satisfied with the school principal - supervisor who is perceived as the creator of such goals, values and beliefs. Since school principals are administrators and supervisors at the same time, the relation between SC2 Professional Treatment by the Administration and JS3 - Supervision is understandable. So, if teachers are satisfied with how they are treated by the school administration, they are also likely to be satisfied with supervision. The negative regression coefficient between SC3 - Teacher Collaboration and JS3 - Supervision means that the more teachers collaborate the more they are dissatisfied with their supervisor. One explanation is that collaboration among teachers is directed towards maintaining the status quo. Sometimes teachers are unwilling to accept the changes initiated by their principal, fearing that they could disrupt their daily routine, so they stick together feeling dissatisfied with the principal, and try to block initiatives and processes of change. Another explanation is that the better and stronger collaboration among teachers who have innovative and useful ideas is, the more they will be able to overpower and oppose the bad quality of supervisors they are dissatisfied with. Finally, sometimes teachers' collaborative working relationships are not spontaneous and voluntary, but may on the contrary be characterized as compulsory and administratively regulated and controlled, which refers to "contrived collegiality" (Hargreaves, 1994).

According to Table 3, dependent variables JS4 - Fringe benefits and JS5 - Contingent rewards are under the influence of SC2 - Professional Treatment by the Administration. In Serbia, teachers are rewarded mainly on the basis of years of teaching experience. This may be very demotivating, especially for those teachers who achieve great results since regardless of a teacher's professional commitment and achievements all of them will receive the same rewards for a certain number of years spent in the profession. Odden (2001), claims that rewarding experience may cause talented teachers to leave the profession because excellence is not fairly rewarded. In school cultures where teachers are professionally treated, principals must know the quality of every teacher and must observe and evaluate their performance. Only in that kind of school culture can teachers be rewarded according to the results they achieve, which will in turn raise the level of their satisfaction and motivate them to perform at their best. Whether they are financial or non-financial (recognition, influence, learning new skills, personal growth), performance-based rewards and benefits are about motivating people, and developing performance-oriented cultures (Tomlinson, 2000).

Based on the value R2, it can be seen that teachers' satisfaction with Operating Procedures - JS6 $(\mathrm{R} 2=0.195)$ is under the lowest influence of school culture and that teacher satisfaction with operating procedures is influenced by SC2 - Professional Treatment by the Administration. Primary school teachers in Serbia are burdened with too many administrative duties and nonteaching related activities, resulting in increased pressure among teachers thus making it almost impossible for them to focus on their core business which is teaching students. Administrative tasks, documentation and paperwork associated with pupils' assessment, progress, behaviour, report writing and reporting to parents, ineffective meetings and frequent changes of policies and directives governed by the Serbian Ministry of Education prevent teachers in Serbia from raising pupil attainment and achievement. According to the results of regression analysis, the support provided by the school administration can to a great extent help teachers to cope with this bureaucratic burden and other nonteaching demands. If school administrators are concerned with reducing pressure on teachers and give them more time to undertake bureaucratic tasks, if they respect teachers' autonomy, professionalism and ability to self-evaluate the progress of their students, and if they organize worthwhile and productive meetings, teachers will be more satisfied 
with the different operating procedures they have to face on a daily basis and dedicate themselves to teaching. Principals who work to reduce teacher frustrations (e.g., administrative paperwork) increase teacher job satisfaction (Blasé \& Roberts, 1994). According to Grayson and Alvarez (2008), by increasing the amount of time and resources for teachers to focus their attention on learning activities, teachers are likely to experience higher levels of personal accomplishment and therefore higher levels of job satisfaction.

Dimension SC1 - Teacher Professionalism and Goal Setting stands out as a significant predictor of the following dimensions of job satisfaction of teachers: JS7 - Co-Workers, JS8 Nature of Work and JS9 - Communication. Teachers who have a clear vision of what they want for their students, who are persistent in their willingness to improve professional knowledge, and stand behind their educational goals, values and beliefs are more satisfied with other colleagues and see them as trustworthy, reliable, competent, honest and open. Those teachers show more interest in communicating constructively with fellow teachers, do not hesitate to express their opinions and consider communication as useful if it is directed towards increasing the quality of teaching and better student outcomes. In her study Tschannen-Moran (2009) found that teachers in highly professional schools respect their colleagues' competence and expertise, work cooperatively with other colleagues, are clearly engaged in the teaching process, and are enthusiastic about their work. According to McLaughlin and Talbert (2001), in professional learning communities teachers recognize their interdependence, have high standards for their work, readily share what they know, and promote continuous learning by all.

Table 4 shows that there is a strong correlation between the dimensions of school culture and those of teacher job satisfaction for both men and women. Hierarchical regression analysis, presented in Table 5, however, shows four relations in which there is a moderating effect of gender. It should be noted that the moderating effect of gender can be seen in only two dimensions of job satisfaction: JS4 - Fringe Benefits and JS6 - Operating Procedures. School culture has a greater influence on female teachers' satisfaction with Operating Procedures - JS6 than on that of their male counterparts. Besides being teachers, female teachers also have their families to take care of. Spending time on administrative duties and non-teaching related activities makes them not only unable to focus on teaching students, but also unable to focus on their role as mothers since they have to sacrifice their private time to finishing the paperwork that they cannot possibly finish during their regular working hours. Also, female teachers may feel required to make a double emotional investment through caring both in the school and in the home, leading to extensive emotional exhaustion (Byrne, 1991). Therefore, a supportive and collaborative school culture with understanding administrators has a greater impact on female teachers' satisfaction with Operating Procedures, because by working in that kind of school culture female teachers can more easily balance their work and family life. By their nature, women are more concerned with the working environment and understanding administrators than men. That is due to their higher sensitivity and insecurity. So, when they are treated supportively by administrators (which is of great importance for them), female teachers tend to be more satisfied with the Fringe Benefits - JS4 that are given by those administrators.

Table 6 shows that there is a strong correlation between the dimensions of school culture and the job satisfaction of teachers in all three age groups of teachers (young teachers, middleaged teachers and older teachers). Also, it can be seen that school culture has the greatest influence on young Serbian primary school teachers' job satisfaction. This finding is consistent with the study of Brown and Wynn (2009) which showed that school culture was one of the most important factors that make young teachers feel happy and satisfied in their schools. Less experienced teachers need to familiarize themselves with the specific context of their school (Elchardus et al., 2009), they try to adjust to the organizational climate of the school and its environment (Vonk, 1995), and attach great importance to it. 
Hierarchical regression analysis shows nine relationships in which there is a moderating effect of age. A moderating influence is present at all three dimensions of school culture: SC1 Teacher Professionalism and Goal Setting, SC2 - Professional Treatment by the Administration, and SC3 - Teacher Collaboration, as well at four dimensions of job satisfaction: JS4 - Fringe Benefits, JS6 - Operating Procedures, JS7 - Co-Workers and JS9 - Communication. Table 7 indicates that the moderating effect of age in dimension JS4 - Fringe Benefits has the following direction: SC1 - Teacher Professionalism and Goal Setting and SC2 - Professional Treatment by the Administration have a greater influence on younger teachers' satisfaction with fringe benefits than on that of their older colleagues. The more novice teachers consider themselves as a part of the school's professional community and see school administrators as supportive and reliable the more they are satisfied with fringe benefits such as free weekends or annual vacations (for Serbian teachers, they are usually in summer and winter), which can be used for further study, training or preparing for lessons and the new school year. Because they are more enthusiastic and idealistic about teaching, younger teachers more than their older peers see fringe benefits as a reward for their professional skills and commitment. On the contrary, older teachers lose that enthusiasm over the years, have lower expectations and are more aware of the true value of fringe benefits.

As can be seen in Table 7, age is a moderator in the relationship between SC2 Professional Treatment by the Administration and JS6 - Operating Procedures, indicating that professional treatment by the administration increases younger teachers' satisfaction with operating procedures. When they start their teaching careers young teachers usually do not expect to have to deal with administrative tasks, documentation and paperwork, but facing the school reality they feel quite discouraged due to the overload of tasks and demands which are not directly related to teaching. Therefore, for younger teachers it is more important that school administrators are supportive, directive and concerned about how they are coping with their work, and that they give them more time to undertake bureaucratic tasks, and the opportunity to talk about any problems or difficulties. Working in a school culture with caring administrators, young teachers become more satisfied with operating procedures, which enables them to handle the first period of their professional careers more easily. On the contrary, older teachers are less concerned about the relationships with their school administrators and need less supervisory direction (de Vries, Roe, \& Taillieu, 1998).

The moderating effect of age also exists in the relationship between all three dimensions of school culture (SC1 - Teacher Professionalism and Goal Setting, SC2 - Professional Treatment by the Administration and SC3 - Teacher Collaboration) and teachers' satisfaction with Co-Workers - JS7. It can be seen that with increasing age, the influence of school culture on teachers' satisfaction with co-workers decreases. Because of the culture shock they experience at the beginning of their professional careers, it is of greater importance for younger teachers to work in a school culture which supports collegial relationships and makes them feel part of a team collaborating closely with veteran and novice colleagues. This finding is not surprising given that younger teachers consider collegiality more important than older school members (Brunetti, 2001), and that the interactions they experience with other colleagues are rooted in the school culture (Koberg \& Chusmir, 1987). Young teachers must rely on knowledgeable colleagues and professional communities for ideas and advice about how to teach (Johnson \& Birkeland, 2003), but they seek not only to take but also to give ideas, resources, observations, and encouragement (Bieler, 2012). If school culture enhances the working environment where younger teachers feel accepted and respected by their colleaugues, they will be more satisfied with them. Satisfaction with co-workers and the opportunity to have joint planning with other teachers, or to participate in regularly scheduled collaboration activities, reduce the risk of younger teachers leaving the profession (Smith \& Ingersoll, 2004). 
The moderating effect of age in the relationship between all three dimensions of school culture and teacher satisfaction with Communication - JS9, indicates that school culture has the greatest influence on younger teachers' communication satisfaction. Insecurity, and a lack of confidence and experience often make young teachers hesitate to freely communicate with other colleagues, especially those more experienced. Therefore, in a school culture that promotes clear communication and an atmosphere of dialogue, and allows the discussion of problems encountered in the school and possible needs, younger teachers will overcome communication barriers more easily and be more satisfied with the quality of communication they have with their fellow teachers.

\section{CONCLUSION}

This study has demonstrated that there are strong correlations between the dimensions of school culture and job satisfaction among teachers in Serbian primary schools. The implications of these findings for professional practice and those who participate in school life are significant, because school culture has been shown to influence primary teachers' job satisfaction. Considering that school culture can be improved, it is possible to improve teachers' job satisfaction as well. Efforts to increase job satisfaction among teachers can be made with a positive, supportive and collaborative school culture. When structuring educational policies, Serbian policy makers should pay close attention to how different aspects of teacher job satisfaction are built in and associated with school culture. They can raise Serbian primary teachers' job satisfaction to a higher level by incorporating mechanisms that will encourage professional development and teacher involvement in the planning process, decision making and implementation of change in the education system.

Since school leaders are the most important factors in shaping, improving and changing school culture, they are in turn the most responsible for creating a school work environment where teachers can thrive and be satisfied with their jobs. That may be achieved if school leaders instil and insist on the value of collegiality and collaboration, mutual honesty, respect and understanding and on healthy school culture norms that will influence how school professionals think, feel and behave towards each other, taking into account the differences between teachers especially in terms of gender and age. By ensuring that younger teachers have appropriate assignments and a manageable workload, and that they can count on their fellow colleagues for advice and support, school administrators can help them adjust to school norms, values and beliefs and enhance novice teachers' retention. The fact that professional treatment by the administration has the greatest influence on teachers' job satisfaction points to the importance of the management function in schools. At the same time, it indicates that the job satisfaction of teachers can be improved through additional training, seminars, courses and workshops in the field of leadership and management in schools in Serbia which should be organized for the school principals.

School leaders cannot accomplish changes and improvements to school culture without the support of all school members, especially teachers. The results of this study can help primary teachers in Serbia become aware of some aspects of their profession they may have neglected (such as the importance of collegiality and togetherness), reconsider their attitudes, beliefs and values, and perceive how certain changes would contribute to their personal satisfaction with the profession, and thus to the quality of their teaching, to better student achievement, as well as to Serbian primary school effectiveness as a whole.

\section{REFERENCES}

Anderman, E. M., Belzer, S., \& Smith, J. (1991). Teacher commitment and job satisfaction: The role of school culture and principal leadership. Paper presented at the the meeting of the American Educational Research Association, Chicago, IL. 
Aydin, A., Sarier, Y., \& Uysal, Ş. (2011). The effect of gender on organizational commitment of teachers: A meta analytic analysis. Educational Sciences: Theory \& Practice 11(2), 628-632.

Beck, L., \& Murphy, J. (1996). The four imperatives of a successful school. Thousand Oaks, CA: Corwin.

Bieler, D. (2012). What new teachers want from colleagues. Educational Leadership, 69(8), 46-49

Blasé, J., \& Roberts, J. (1994). The micropolitics of teacher work involvement: Effective principals' impact on teachers. Alberta Journal of Educational Research, 40(1), 67-94.

Block, A. W. (1983). Effective schools: A summary of research. Arlington, VA: Educational Research Service.

Bolman, L., \& Deal, T. (1997). Reframing organizations: Artistry, choice, and leadership (2nd ed.). New York, NY: John Wiley.

Brackett, M. A., Palomera, R., Mojsa-Kaja, J., Reyes, M. R., \& Salovey, P. (2010). Emotion-regulation ability, burnout, and job satisfaction among British secondary-school teachers. Psychology in the Schools, 47(4), 406-417.

Brown, K. M., \& Wynn, S. R. (2009). Finding, supporting, and keeping: The role of the principal in teacher retention issues. Leadership and Policy in Schools, 8(1), 37-63.

Brunetti, G. J. (2001). Why do they teach? A study of job satisfaction among long-term high school teachers. Teacher Education Quarterly, 28(3), 49-74.

Butt, G., \& Lance, A. (2005). Secondary teacher workload and job Satisfaction: Do successful strategies for change exist? . Educational Management Administration \& Leadership, 33(4), 401-422.

Byrne, B. M. (1991). Burnout: Investigating the impact of background variables for elementary, intermediate, secondary and university educators. Teaching and Teacher Education, 7(2), 197-209.

Chen, Y., \& Sun, S. (1994). A study on the measurement of teacher job satisfaction. Psychology Science, 17(3), 146149.

Cheng, Y. C. (1993). Profiles of organizational culture and effective schools. School Effectiveness and School Improvement, 4(2), 85-110.

Clement, M., \& Vandenberghe, R. (2000). Teachers' professional development: a solitary or collegial (ad)venture? Teaching and Teacher Education, 16(1), 81-101.

Cockburn, A. D. (2000). Elementary teachers' needs: issues of retention and recruitment. Teaching and Teacher Education, 16(2), 223-238.

Darling-Hammond, L. (1995). Policy for restructuring. In A. Lieberman (Ed.), The work of restructuring school: Building from the ground up (pp. 157-175). New York: Teachers College Press.

De Nobile, J. J., \& McCormick, J. (2008). Organizational communication and job satisfaction in Australian Catholic primary schools. Educational Management Administration \& Leadership, 36(1), 101-122.

De Vries, R. E., Roe, R. A., \& Taillieu, T. C. B. (2002). Need for leadership as a moderator of the relationships between leadership and individual outcomes. Leadership Quarterly, 13(2), 121-137.

Deal, T. E., \& Kennedy, A. A. (1999). The new corporate cultures: Revitalizing the workplace after downsizing, mergers and reengineering. New York, NY: Perseus Publishing.

Demirtas, Z. (2010). The relationship between school culture and student achievement. Egitim Ve Bilim-Education and Science, 35(158), 3-13.

Dinham, S. (1995). Time to focus on teacher satisfaction. Unicorn, 21(3), 64-75.

Dinham, S., \& Scott, C. (1998). A three domain model of teacher and school executive satisfaction. Journal of Educational Administration, 36(4), 362-378.

Edwards, J. L., Green, K. E., \& Lyons, C. A. (1996). Factor and Rasch Analysis of the School Culture Survey. Paper presented at the the Annual Meeting of the American Educational Research Association, New York. 
Elchardus, M., Huyge, E., Kavadias, D., Siongers, J., \& Vangoidsenhoven, G. (2009). Leraars: Profiel van een beroepsgroep. [Teachers: Profile of a professional group]. Leuven: Lannoo Campus.

Engels, N., Hotton, G., Devos, G., Bouckenooghe, D., \& Aelterman, A. (2008). Principals in schools with a positive school culture. Educational Studies 34(3), 159-174.

Fullan M. (2001). Leading in a Culture of Change. San Francisco, CA: Jossey-Bass.

Fullan M. (2007). The New Meaning of Educational Change. New York: Teachers College Press.

Fyans, L. J., Jr., \& Maehr, M. L. (1990). School culture, motivation, and achievement (Project Report). Urbana: University of Illinois.

Grayson, J. L., \& Alvarez, H. K. (2008). School climate factors relating to teacher burnout: A mediator model. Teaching and Teacher Education 24(5), 1349-1363.

Hancock, C. B., \& Scherff, L. (2010). Who will stay and who will leave? Predicting secondary English teacher attrition risk. Journal of Teacher Education, 61(4), 328-338.

Hargreaves, A. (1993). Individualism and individuality: Reinterpreting the teacher culture. International Journal of Educational Research, 19(3), 227-246.

Hargreaves, A. (1994). Changing teachers, changing times: Teachers' work and culture in the Postmodern Age. London: Cassell.

Heck, R. H., \& Marcoulides, G. A. (1996). School culture and performance: Testing the invariance of an organizational model. School Effectiveness and School Improvement, 7(1), 76-95.

Ingersoll, R. M., \& Smith, T. M. (2003). The wrong solution to the teacher shortage. Educational Leadership, 60(8), $30-33$.

Johnson, S. M., \& Birkeland, S. E. (2003). Pursuing a "sense of success": New teachers explain their career decisions. American Educational Research Journal, 40(3), 581-617.

Kalleberg, A. L., \& Loscocco, K. A. (1983). Aging, values, and rewards: explaining age differences in job satisfaction. American Sociological Review, 48(1), 78-90.

Kim, S. (2002). Participative management and job satisfaction: Lessons for management leadership. Public Administration Review, 62(2), 231-241.

Koberg, C. S., \& Chusmir, L. H. (1987). Organizational culture relationships with creativity and other job-related variables. Journal of Business Research, 15(5), 397-409.

Kwong, J., Wang, H., \& Clifton, R. A. (2010). Rethinking our assumptions about teachers' job satisfaction in China and the West. Australian Journal of Education, 54(2), 115-132.

Ladebo, O. J. (2005). Effects of work-related attitudes on the intention to leave the profession: An examination of school teachers in Nigeria. Educational Management Administration \& Leadership, 33(3), 355-369.

Lester, P. E. (1982). Teacher job satisfaction questionnaire. Brookville, New York: Long Island University

Levine, D. U., \& Lezotte, L. W. (1990). Unusually effective schools: A review and analysis of research and practice. Madison, WI: National Center for Effective Schools Research and Development.

Lewis, K. S., \& Wahlstrom, K. (2011). Principals as cultural leaders. Kappan, 92(5), 52-56.

Lindahl, R. A. (2006). The role of organizational climate and culture in the school improvement process: A review of the knowledge base. Educational Leadership Review, 7(1), 19-29.

Ma, X., \& MacMillan, R. B. (1999). Influences of workplace conditions on teachers' job satisfaction. The Journal of Educational Research, 93(1), 39-47.

McLaughlin, M. W., \& Talbert, J. E. (2001). Professional communities and the work of high school teaching. Chicago: University of Chicago Press.

Odden, A. (2001). Defining Merit. Education Matters, 1(1), 16-24. 
Osborn, M., McNess, E., Broadfoot, P., Pollard, A., \& Triggs, P. (2000). What teachers do: changing policy and practice in primary education. London: Continuum.

Owens, R. G. (2004). Organizational behavior in education: Adaptive leadership and school reform (8th ed.). Boston, MA: Allyn and Bacon.

Pavlović, N., \& Oljača, M. (2011). Organizational culture and performance of schools. Pedagogy, 1(1), 10-24.

Saphier, J., \& King, M. (1985). Good seeds grow in strong cultures. Educational Leadership, 42(6), 67-74.

Schein, E. H. (1985). Organizational culture and leadership. San Francisco: Jossey-Bass.

Schonfeld, I. S. (2000). Short research paper: An updated look at depressive symptoms and job satisfaction in first-year women teachers. Journal of Occupational and Organizational Psychology, 73(3), 363-371.

Seifer, E. H., \& Vornberg, J. A. (2002). The new school leader for the 21st century: The principalship. Lanham, MD: Scarecrow Press.

Sergiovanni, T. J. (1984). Leadership and excellence in schooling. Educational Leadership, 41(5), 4-13.

Skaalvik, E. M., \& Skaalvik, S. (2009). Does school context matter? Relations with teacher burnout and job satisfaction. Teaching and Teacher Education 25(3), 518-524.

Skaalvik, E. M., \& Skaalvik, S. (2011). Teacher job satisfaction and motivation to leave the teaching profession: Relations with school context, feeling of belonging, and emotional exhaustion. Teaching and Teacher Education, 27(6), 1029-1038.

Smith, T. M., \& Ingersoll, R. M. (2004). What are the effects of induction and mentoring on beginning teachers' turnover? American Educational Research Journal, 41(3), 681-714.

Spector, P. E. (1985). Measurement of human service staff satisfaction: Development of the job satisfaction survey. American Journal of Community Psychology, 13(6), 693-713.

Spector, P. E. (1997). Job satisfaction: Application, assessment, cause, and consequences. Thousand Oaks, CA: Sage Publications, Inc.

Statistical Office of the Republic of Serbia (2011). Women and men in the Republic of Serbia, Belgrade.

Stockard, J., \& Lehman, M. B. (2004). Influences on the satisfaction and retention of 1st-year teachers: The importance of effective school management. Educational Administration Quarterly, 40(5), 742-771.

Stolp,S. \& Smith, S. (1994) School culture and climate: The role of the leader. OSSC Bulletin. Eugene: Oregon School Study Council.

Tomlinson, H. (2000). Proposals for performance related pay in English schools. School Leadership and Management, 20(3), 281-298.

Tschannen-Moran, M. (2009). Fostering teacher professionalism in schools: The role of leadership orientation and trust. Educational Administration Quarterly, 45(2), 217-247.

Van Den Berg, R. (2002). Teachers' meanings regarding educational practice. Review of Educational Research, 72(4), 577-625.

Vonk, J. H. C. (1995). Conceptualizing novice teachers' professional development: A base for supervisory interventions. Paper presented at the the annual conference of AERA, San Francisco, CA.

Waller, W. (1932). The sociology of teaching. New York, NY: Wiley.

Weiqi, C. (2008). The structure of secondary school teacher job satisfaction and its relationship with attrition and work enthusiasm. Chinese Education and Society, 40(5), 17-31.

Wong, C. S., Wong, P. M., \& Peng, K. Z. (2011). Effect of middle-level leader and teacher emotional intelligence on school teachers' job satisfaction: The case of Hong Kong. Educational Management Administration \& Leadership, 38(1), 59-70.

Wu, V., \& Short, P. M. (1996). The relationship of empowerment to teacher job commitment and job satisfaction. 
Journal of Instructional Psychology, 23(1), 85-89.

Xiaofu, P., \& Qiwen, Q. (2008). An analysis of the relation between secondary school organizational climate and teacher job satisfaction. Chinese Education and Society, 40(5), 65-77.

Zembylas, M., \& Papanastasiou, E. (2004). Job satisfaction among school teachers in Cyprus. Journal of Educational Administration, 42(9), 357-374.

\section{Genişletilmiş Özet}

Her okul bir temsil kültürünü temsil eder (Sergiovanni, 1984). Temsil kültürünü tarif etmek, çalışan öğretmenlerin, öğrencilerin, ebeveynlerin ve yöneticilerin zaman içinde geliştirdiği gelenek ve ritüelleri kapsayan bir ağ içerdiğinden tanımlamak zordur (Deal \& Kennedy, 1999). Seifert ve Vornberg (2002) paydaşların tutum ve inançlarının, okulun kültürel normları ve okuldaki bireyler arasındaki ilişkileri, hem içeride hem de dışarıda, okul kültürüyle etkileşim içinde olduğunu iddia etmektedirler. Her okulun başarısı oluşturduğu kültüre bağlıdır (Saphier \& King,1985). Pozitif okul kültürünün bir okulun farklı yönleri ile ilgili olduğunu teyit eden birçok referans vardır: Öğrencilerin başarıları, isteklendirilmeleri ve öğrenmeleri (Fyans \& Maehr, 1990; Heck \& Marcoulides, 1996; Engels et al. 2008; Demirtas, 2010; Lewis \& Wahlstrom, 2011), okul gelişimi ve etkinliği (Lezotte, 1990; Fullan, 2001),öğretmenlerin profesyonel gelişimi, bağlılık ve verimlilik (Cheng, 1993; Fullan, 2001; Owens, 2004; Engels et al. 2008) ve öğretmenlerin iş doyumu (Anderman, Belzer \& Smith, 1991; Stolp \& Smith, 1994; Chen \& Sun, 1994; Ma \& MacMillan, 1999; Hancock \& Scherff, 2010).

Öğretmen iş doyumu; bir öğretmenin öğretmenlik rolüne ya da o rolle olan ilişkisiyle alakalıdır. Öğretmen iş doyumu; bir öğretmenin öğretmenliğe yüklediği anlam ve bir öğretmenden beklediği şey arasındaki ilişkiyle alakalıdır (Zembylas \& Papanastasiou, 2004). Lester (1982) öğretmen iş doyumunu bir öğretmenin algıları ve değerlendirme, iş birliği, sorumluluk ve tanıma gibi çeşitli değer faktörlerine göre tanımlar. Dinham (1995) öğretmenin iş doyumunu ilk olarak öğrencilerle olan ilişkilerinden (mevcut ve geçmiş) ve ikinci olarak ebeveynler ve meslektaşları ile olan ilişkilerinden elde etiğini iddia eder.

Okul kültürünü ve öğretmen iş tatmini arasındaki ilişkiyi anlamak çok önemlidir. Eğer bütün okul üyeleri bu değişim ve gelişimin önemini kavrarlarsa okul kültürünü geliştirmek için birlikte çalışırlar. Okul kültürünü gelişerek öğretmenin iş memnuniyetini arttırmak mümkündür ki bu durum Sırp ilköğretim okullarının etkinliği üzerinde olumlu bir etkisi olabilir. Daha da fazlası Sırbistan'da öğretmenler arasında iş memnuniyetinin azalmasına yol açan Sırbistan'da eğitim sistemine geçiş sürecinde son birkaç on yıl boyunca ilköğretim okullarında yaşanan birçok zorluklarla ve sorunları aşmaya da katkı sunabilir.

Okul Kültürü Anketi (Saphier ve Kral, 1985; Edwards, Green \& Lyons, 1996 da geliştirilmiş) okul kültürünü ölçmek için kullanılmıştır. Bu üç boyutu içerir: Öğretmen Profesyonelliği ve Hedef Belirleme, İdare tarafından muamele. Aynı zamanda öğretmenlerin iş doyumu dokuz boyutlu İş Memnuniyeti Anketi (Spector, 1985) ile de ölçülmektedir. Bu boyutlar; İş Ücreti, Promosyon, Denetleme, Sosyal Yardım, Grup Ödülleri, Çalışma Usulü, İşbirliğí, İşin Niteliği ve İletişimdir. Bu çalışmaya Sırbistan'da bulunan 57 ilköğretim okulundan 362 öğretmen dâhil edilmiştir. Anketler bu okullardaki tüm öğretmenlere bizzat dağıtılmış ve onların verdikleri yanıtlar sayesinde okul kültürü ve iş memnuniyeti hakkındaki görüşleri ortaya çıkmıştır. Katılımcıların 250 si kadın ve112 erkektir. Yaşlarına göre özneler üç gruba ayrılmıştır: genç öğretmenler, orta yaştaki öğretmenler ve yaşlı öğretmenler.

Araştırma sonuçları tanımlayıcı istatistikler, korelasyon analizi, çoklu regresyon analizi ve hiyerarşik regresyon analizi uygulayarak elde edilmiştir. Bu gruplandırmadaki amaç cinsiyet ve yaşın okul kültürünün boyutları ve öğretmenlerin iş tatmini üzerindeki etkilerini tespit etmekti. Sonuçlar, okul kültürünün her üç boyutunun doğrudan öğretmenlerin iş doyumu ile ilişkili olduğunu göstermektedir. Ancak, İdare tarafından Profesyonel muamele bunlar arasında en güçlü etkiye sahiptir. Cinsiyet ve yaş okul kültürü ve iş doyumu arasındaki ilişkiyi belirleyen faktörlerdir. Hem kadın ve hem de erkekler arasında okul kültürü ve öğretmen iş doyumu arasında güçlü bir ilişki olduğu tespit edilmiştir. Ayrıca, her üç yaş grubu öğretmenlerinde de okul kültürü ve iş doyumu arasında arasında güçlü bir ilişki vardır. Hiyerarşik regresyon analizi sonuçları cinsiyetin, iş tatmininin Sosyal Haklar ve Çalışma Usulü boyutuyla, yaşın İş Tatmini; Sosyal Haklar, Çalışma Usulü, İşbirliği ve İletişim boyutuyla ilişkili olduğunu göstermektedir.

$\mathrm{Bu}$ çalışma, Sırp ilköğretim okullarındaki öğretmenler arasında okul kültürü ve iş tatmini boyutları arasında güçlü bir ilişki olduğunu ortaya koymuştur. Okul kültürü öncelikle öğretmenlerin iş doyumunu 
etkilediğinden, okul hayatında katılan profesyonel uygulama için bu bulguların etkileri önemlidir. Sırp politikacılar, öğretmenleri profesyonel gelişim ve planlama süreçlerine, karar verme ve eğitim sistemindeki değişikliklerin uygulanmasına dâhil ederek onların iş tatmini yükseltebilirler. Okul liderleri, okul kültürünü şekillendiren geliştiren ve değiştiren en önemli faktörlerdir. Meslektaşların işbirliği, karşılıklı güven, saygı ve anlayış sağlıklı okul kültürü normlarının sağlamasına katkı sağlayacaktır. Sağlıklı okul kültürü normları sayesinde cinsiyet ve yaş bakımından öğretmenler arasındaki farklar dikkate alınarak onların nasıl düşündüğünü, hissettiğini ve birbirine karşı tutumları anlaşılabilir bir durum haline gelecektir. $\mathrm{Bu}$ çalışmanın sonuçları, Sırbistan'da ilköğretim öğretmenlerinin göz ardı ettikleri bazı mesleki yönlerinin (işbirliği ve beraberliğin önemi gibi) farkına varmalarını sağlayacaktır. Ayrıca öğretmenlerin inanç ve değerlerini yeniden gözden geçirmelerine firsat vererek, hangi mesleki değişimlerin kendi kişisel memnuniyetlerine katkı sağlayacağını görmelerine yardımcı olacaktır. Bu sonuçlar aynı zamanda bütün Sırbistan'daki ilkokullardaki öğrenci başarısına da katkı sunacak ve bir bütün olarak eğitim kalitesinin artmasına yardımcı olabilecektir. 